Neurális hálók

aszfalttechnológiai alkalmazása

KONCSOS TAMÁS - BME Vízi Közmú és Környezetmérnöki Tanszék - bonsalty@gmail.com
TÓTH CsABA - BME Út és Vasútépítési Tanszék - toth@uvt.bme.hu
Érkezett: 2012.03.25. - Received: 25.03.2012. http://dx.doi.org/10.14382/epitoanyag-jsbcm.2012.6

\title{
Asphalt technological application of the neural network
}

The article depicts a possible asphalt technological application of the neural network using the data of the numerous stiffness tests of three domestic asphalt mixtures. The results reinforce the preliminary expectations by which the MLP (Mutilayer Perceptron) network built upon the tests results specified by indirect tensional tests is capable of prognosticating the stiffness very precisely in the trained range. Although the possible drawback of the method may be observed in its inexact extrapolating ability, it can be improved by the continuous development of the database furthermore managed having produced a combined map using the Kohonen map just as in this present work. The article verifies that the estimation of the stiffness of the mixtures made with the help of the neural network is a lot better than those applied at the traditional models, furthermore draws the attention to the fact that the superbness of the neural network lies exactly with their universality and the optional feature of the mixtures can be tested and prognosticated in the future with their help.

\section{Az aszfaltkeverékek merevségének jelentősége}

Sajnos ma sem állíthatjuk, hogy a hazai aszfaltreológiai kutatások a világ élvonalba tartoznának, azonban ennek fényében különösen örvendetes, hogy egy korábbi szakmai döntés nyomán az aszfaltkeverékek tervezési követelményeinek meghatározása vonatkozásában az empirikus előírásokkal szemben a fundamentális előírások kerültek rögzítésre. Ezen döntésnek köszönhetően azonban a teljesítményalapú követelmények és az ezekhez rendelt, elsősorban a keverékek fáradásával, illetve merevségével kapcsolatos vizsgálatok jelentősége is megnőtt.

Az EN 13108-20:2006 európai szabvány - ez elv szerint - az aszfaltkeverékek tulajdonságainak esetében megkülönbözteti vizsgálati módszereit, például:

- performance-related (leistungsbezogen): vízérzékenység, üzemanyag-állóság, maradó alakváltozással szembeni ellenállás kis, illetve nagy kerekes nyomvályúvizsgáló vizsgálórendszer esetén,

- performance-based (leistungsbasierend): merevség, fáradás, maradó alakváltozással szembeni ellenállás triaxiális vizsgálat esetén.

Az 1. ábra a teljesítményelvű és teljesítményalapú vizsgálatok közötti finom különbség demonstrálására tesz kísérletet.
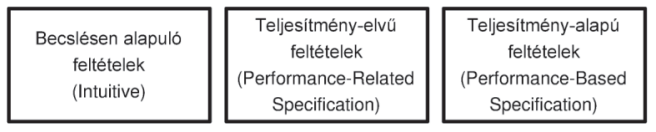

Teljesitöképesség
(Performance Specification)

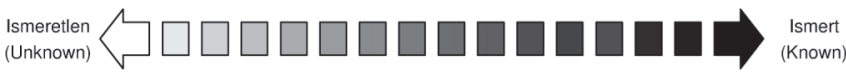

A teljesítmény viszonyítása

1. ábra A teljesitmény szintek illusztrációja (Tóth, 2006)

Fig. 1. Illustration of various levels of performance specifications (Tóth, 2006)

A teljesítményalapú aszfaltvizsgálatok kiemelt jelentőségével egyetértve a BME Út és Vasútépítési tanszékén - a rendelkezésre álló forrásokhoz mérten - jelentős kutatások folynak
Dr. то́тH Csaba Okl. épitoômérnök, MBA, PhD. A Magyar Mérnöki Kamara és a Magyar Útügyi Társaság Útpályaszerkezetek Szakbizottság tagja, jelenleg az BME Út és Vasútépitési Tanszék adjunktusa. Korábban a Csongrád Megyei Állami Közútkezelō Kht., illetve az Állami Közúti Műszaki és Információs Kht. oszályvezetôjeként a magyar útügyi adminisztrációban dolgozott. Késöbb a Strabag Konszern mérnökeként részt vett az épülő hazai országos közúthálózat minôségellenörzésében, valamint a Konszern nemzetközi és hazai kutatásaiban. Közlekedési épitổmérnöki szakértő́ként, tervezőként, illetve müszaki ellenörként közremüködött számos burkolat-megerỗśtési projektben. Kutatási területe: hajlékony útpályaszerkezetek igénybevétele, méretezése, teherbirio-képessége, megerôsitése. Publikációinak száma: több mint 30 .

kONCSOS Tamás Okl. épitoômérnök, jelenleg a BME Vízi Közmû́ és Környezetmérnöki Tanszék PhD hallgatója. Korábban a GeneralCom-nál dolgozott programozói munkakörben, illetve a BME VKKTval közösen folytatott WateRisk vízgazdálkodási döntéstámogató rendszer kiépítésében tevékenykedett. Az FVM megbízásában a LeoEpa hálózat szimulációs program tervezője, jelenleg számos hazai kutatási tevékenységben vesz részt. Kutatási tevékenységek: mesterséges intelligencia, lágy számítási módszerek alkalmazása a környezetmérnöki gyakorlatban, neurális hálózatok applikációja optimalizációs feladatok megoldására, szakértổi rendszerek fejlestéese.

Publikációinak száma: 6.

e területen, amelyek nyomán az elmúlt időszakban született értekezések már elsősorban az aszfaltkeverékek merevségével, illetve fáradási tulajdonságaival kapcsolatos kérdésekre is fókuszáltak. A téma aktualitását mutatja továbbá, hogy az aszfaltkeverékek merevsége kapcsán az elmúlt időszakban számos cikk is született. Többek között egy, az aszfaltkeverékek merevségének prognosztizálási lehetőségével kapcsolatos cikkben (Fi-Tóth, 2010) említésre került már a mesterséges neuronhálózatok (ANN, artificial neural network) alkalmazhatósága az aszfaltkeverékek merevségét becslő modellek megalkotása sorában.

Az ANN elvét az emberi idegrendszer, az agy idegsejtjeinek működése ihlette, és noha az 1940-es évek végén kezdődő kutatások eredeti célja az emberi agyfunkciók szimulálására irányult, az ANN modelleket ma már például a statisztikai elemzések vagy az adatfeldolgozás területén is alkalmazzák, többnyire nem-lineáris folyamatok elemzésére. Ezek a modellek azonban elsősorban a mérési eredmények technikai feldolgozása során jelentenek segítséget, erre alapozva azonban különböző becslések kidolgozására is képesek.

Jelen cikkben korábbi kutatások ( $\mathrm{Fi}$ et al, 2009) nyomán született adatbázis segítségével az ANN technika aszfalttechnológiai alkalmazhatóságát demonstráljuk. Felhívjuk azonban a figyelmet arra, hogy ezen elv alkalmazhatósága lényegesen sokoldalúbb, elég, ha csak azon modelleket említjük, amelyek az útpályaszerkezetek Falling Weight Deflectometerrel (FWD) mért behajlási teknőinek kiértékelésére készültek (Saltan et al, 2011), de akár egyszerü laboratóriumi vizsgálatok elemzésére, például Marshall stabilitás elörejelzésére alkalmas modellek is készíthetők (Ozgan, 2011). 


\section{Neurális hálók}

A mesterséges neurális hálózatok alapjait Cajal teremtette meg 1909-ben, amikor a gerincesek tanulmányozása során észrevette, hogy az állatok agya nagyszámú összekötött sejtből áll, amiket neuronoknak nevezett. Azóta igazolódott, hogy ezek képezik az információfeldolgozás alapvető részegységeit. Felfedezték, hogy egy neuronnak vannak olyan ágai, amelyek begyüjtik az érkező ingereket, majd egy másik ágon, továbbítják az erre adott választ.

A neuronok egyszerüsített matematikai modelljét W. S. McCulloch és W. Pitts készítette el 1943-ban. A modellben minden egyes bemenethez rendelhetö egy súly, majd a súlyozott bemenetek összege a neuron átviteli függvényén keresztül adja a kimenetet (2. ábra).

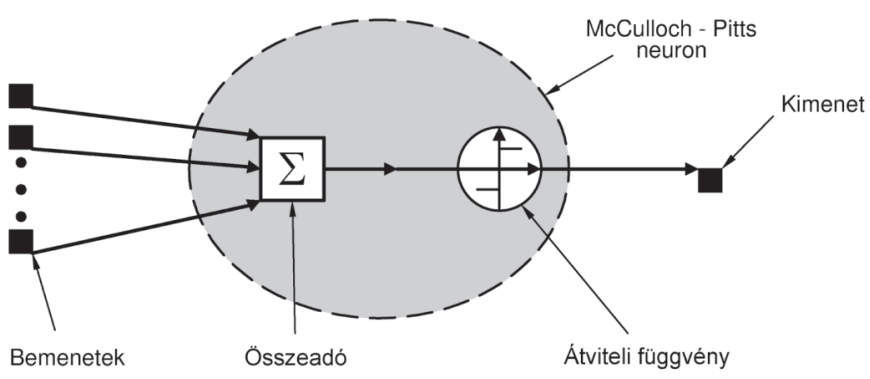

2. ábra A McCullogh-Pitts neuron (Abonyi, 2006)

Fig. 2. The McCullogh-Pitts neuron (Abonyi, 2006)

Ez az összefüggés könnyen algoritmizálható, a kapcsolat az (1) egyenlettel írható le.

$$
y=f\left(\sum_{i=1}^{n} w_{i} \cdot x_{i}\right)
$$

ahol:

$y$ : a neuron kimenete

$\mathrm{f}()$ : átviteli függvény

$\mathrm{w}_{\mathrm{i}}$ : súlytényező

$\mathrm{x}_{\mathrm{i}}$ : a neuron bemenetei (független változók)

A neuron jel-transzformációs képessége speciális, többértékü logikai kapuként is értelmezhető. A súlytényezők megválasztásával a rendszer szűk korlátok között taníthatóvá válik, azaz adott kimeneti jelek állíthatók elő a bemeneti minták alapján. A neuronok összekapcsolásával olyan hálózatokhoz jutunk, melyek már összetett matematikai feladatok megoldására is alkalmasak (adattömörítés, asszociatív memória, rendezés, univerzális függvényközelítés).

Függvényapproximációs célokra a nem rekurrens mesterséges neuron hálózatok leggyakrabban alkalmazott változata az előrecsatolt, többrétegủ háló: MLP (Multilayer Perceptron). Az MLP rétegelt, a réteg fogalma alatt esetünkben egy neuron halmazt értünk, melyekre érvényesek az alábbi megkötések: az összes réteg valamennyi neuronja az elötte és utána álló réteg minden neuronjával kapcsolatban áll, azonban a sejtek nem kapcsolódnak egymáshoz a saját rétegen belül. A bemeneti réteg annyi neuronból áll, ahány bemenő változónk van. Ezek tulajdonképpen jeltovábbítást végeznek a többi csomópont felé. A első rétegben találhatók a rejtett neuronok, amelyek száma tetszőleges lehet. Ezeknek mind a bemenete, mind a kimenete másik csomóponthoz kapcsolódik. Itt folyik a tulajdonképpeni adatfeldolgozás. Matematikailag bizonyított, hogy a kétrétegű MLP elvben bármely folytonos függvény közelítésére alkalmas. Azonban figyelembe véve azt a tényt, hogy a rendelkezésre álló információ mennyisége korlátos és a megoldandó feladat a komplexitás függvényében akár egyszerübb, de összetett módszerekkel is megoldható, a kétrétegủ háló, illetve az MLP topológia sok esetben helyettesítendő. A kimeneti rétegben annyi neuron van, ahány kimeneti változónk van. Ezek továbbítják az információt a külvilág felé. A 3. ábra egy többrétegü háló kialakítást szemléltet.

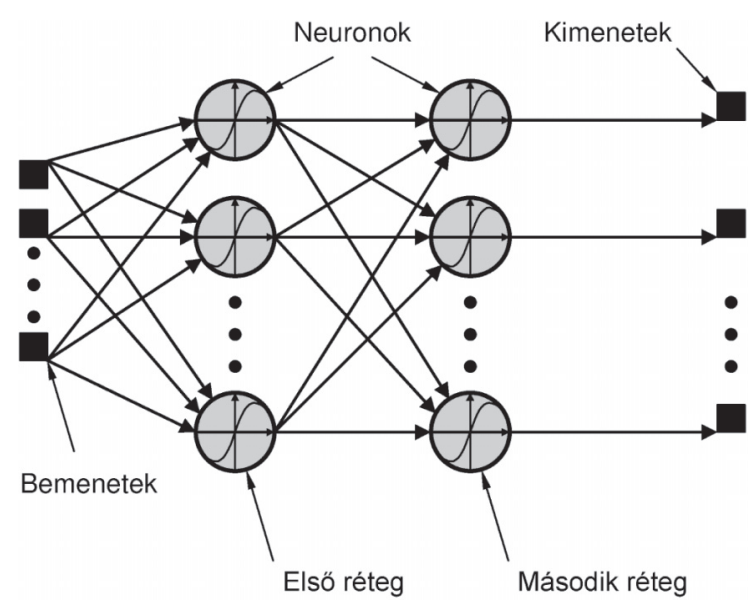

3. ábra A többrétegü neurális háló szerkezete (Abonyi, 2006)

Fig. 3. The structure of the multilayered neural network (Abonyi, 2006)

A teljes MLP hálózat a (2) egyenlettel írható le:

$$
\hat{y}=w_{0}+\sum_{i=1}^{m} w_{i}\left(w_{i 0}+f\left(\sum_{j=1}^{n} w_{i j} \cdot x_{j}\right)\right)
$$

ahol

y: a hálózat kimenete (becsült függő változó)

$\mathrm{f}()$ : átviteli függvény

$\mathrm{w}_{\mathrm{i}}$ : súlytényező

$\mathrm{x}_{\mathrm{j}}$ : a hálózat bemenetei (független változók)

$\mathrm{n}$ : független változók száma

m: neuronok száma a rejtett rétegben

A neurális hálózatot meg kell tanítani a probléma megoldására. Ez jellemzően azt jelenti, hogy valamilyen nemlineáris optimalizációs eljárással keressük azokat a súlytényezőket, amelyeknél a hálózat az adott regressziós feladatot jól meg tudja oldani.

$\mathrm{Az}$ MLP hálózatok legfontosabb tulajdonságai (Abonyi, 2006):

- univerzálisak, a legtöbb regressziós probléma esetén használhatók,

- az extrapolációs tulajdonsága megjósolhatatlan, ezért nagyon fontos hogy a tanítási minta lefedje mind a függő, mind a független változók teljes tartományát,

- megfelelő számú neuron esetén a regressziós modell pontossága jó,

- a neurális háló tanítása lassú, nagy körültekintést igényel, de a modell kiértékelése gyors,

- a kész hálózat nem interpretálható. 


\section{Az adatbázis}

Egy korábbi kutatás keretében (Fi et al, 2009) a kőváz összetételének merevségre gyakorolt hatását vizsgáltuk három keverék esetén. A vizsgált keverékek típusa SMA 11 (F), AC 22 (F) és AC $22(\mathrm{mF})$ volt, három-három különböző kővázzal tervezve. A tervezett szemeloszlások úgy lettek meghatározva, hogy egy-egy, a korábbi hazai szabályozás szerinti alsó, illetve felső határgörbe szemeloszlásának, további egy pedig ezen két szemeloszlás átlagának feleljen meg. Emellett a különböző kővázú keverékek 3-3-féle kötőanyag-tartalommal lettek elóállítva.

A merevségvizsgálatokat - négy különböző hőmérsékleten indirekt húzóvizsgálattal (IT-CY) végeztük. Ez a vizsgálat ugyan alapvetően nem képes különböző terhelési szintek megvalósítására, korábbi kutatásaink alapján azonban azt tételeztük fel, hogy a felfutási idő változtatásával a frekvenciaterhelés jól szimulálható. Ennek érdekében a vizsgálatokat - a szabvány által elöírt 124 msec felfutási idő helyett - négy terhelési szinten: 60 , 90, 120, 150 msec felfutási idővel végeztük.

Figyelembe véve az eltérő szemeloszlás, a különböző kötőanyag-tartalom, illetve terhelési idő és vizsgálati hőmérséklet miatt létrejött változatokat, a merevségvizsgálatok száma keverékenként 144 darab volt, azaz mindösszesen 432 darab merevségvizsgálati eredmény állt rendelkezésre. Az így elöállított adatbázis megteremtette annak lehetőségét, hogy a neurális háló segítségével építsük egy merevség előrejelző modellt és vizsgáljuk annak pontosságát.

\section{Aszfaltkeverék merevség becslő modell MLP hálóval}

Az aszfaltkeverék-merevség előrejelző modell kiépítéséhez először be kell táplálni az input adatokat és az észlelt eredményeket. Minél több keverék-összetételt és a hozzátartozó mért merevségi adatokat táplálunk be egy ilyen rendszerbe, annál pontosabban súlyozódnak az egyes lehetséges összefüggések és annál pontosabb lesz a prognózis.

Az input adatok lehatárolásánál - hasonlóan a nemzetközi gyakorlathoz - a Witczak-féle modell struktúráját (NCHRP, 2004) használtuk a 4. ábrán láthatóak szerint.

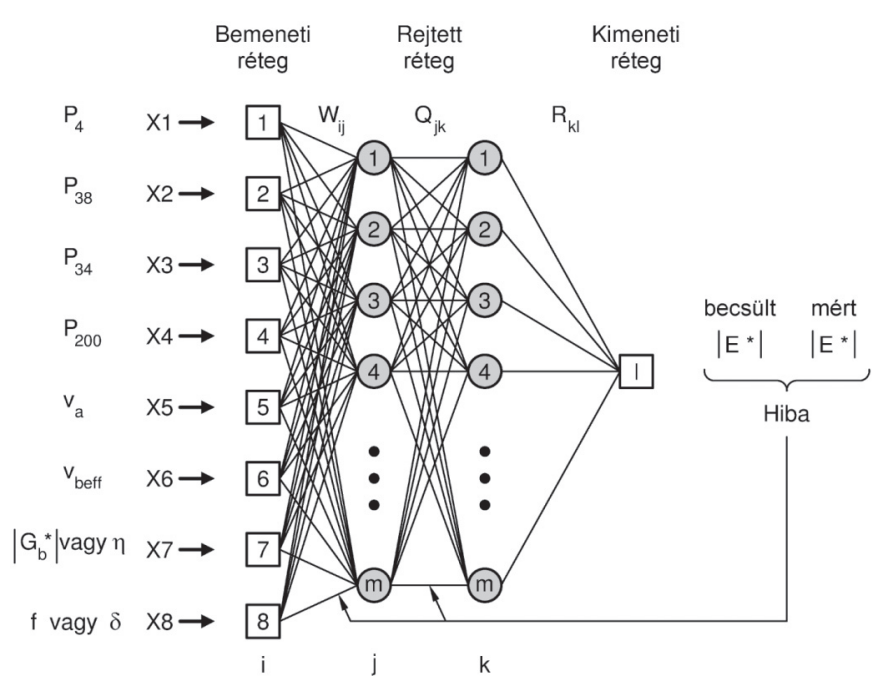

4. ábra Az alkalmazott MLP háló szerkezete

Fig. 4. The structure of the MLP network applied
A nemzetközi gyakorlathoz hasonlóan mi is azt tételeztük fel, hogy a vizsgálati eredményeket 8 paraméter elegendően pontosan határozza meg. A háló készítés során azonban az angolszász szitaméretet a hazai gyakorlatnak megfelelően aktualizáltuk, illetve a terhelési időt nem frekvenciában, hanem az ITCY vizsgálat felfutási idejében adtuk meg. Továbbá a $20^{\circ} \mathrm{C}$-on nehézkesen meghatározható bitumen viszkozitás értékeket nem mértük, hanem penetráció mérés alapján becsültük. Mint az a 4. ábrán látható, a háló input adatai az alábbiak voltak:

- szemeloszlási görbe négy paramétere $\left(\mathrm{p}_{\mathrm{i}}\right)$,

- $\mathrm{V}_{\mathrm{a}}$ : szabadhézag-tartalom,

- $\mathrm{V}_{\text {befi: }}$ kötőanyag-tartalom,

- t: terhelési idő,

- $\quad \eta$ : kötőanyag viszkozitás (penetrációs érték alapján becsült).

Az így felépített MLP hálót a rendelkezésre álló mérési adatbázist kettéosztva, annak 300 mérési eredményének segítségével „tanítottuk be”. Az adatbázisunk második részével, azaz 132 darab mérési eredményével a háló pontosságát vizsgáltuk, validáltuk. A betanító és a validáló futtatások eredményeit összevetve a mérési adatokkal az 5. ábrán látható eredményeket kaptunk.
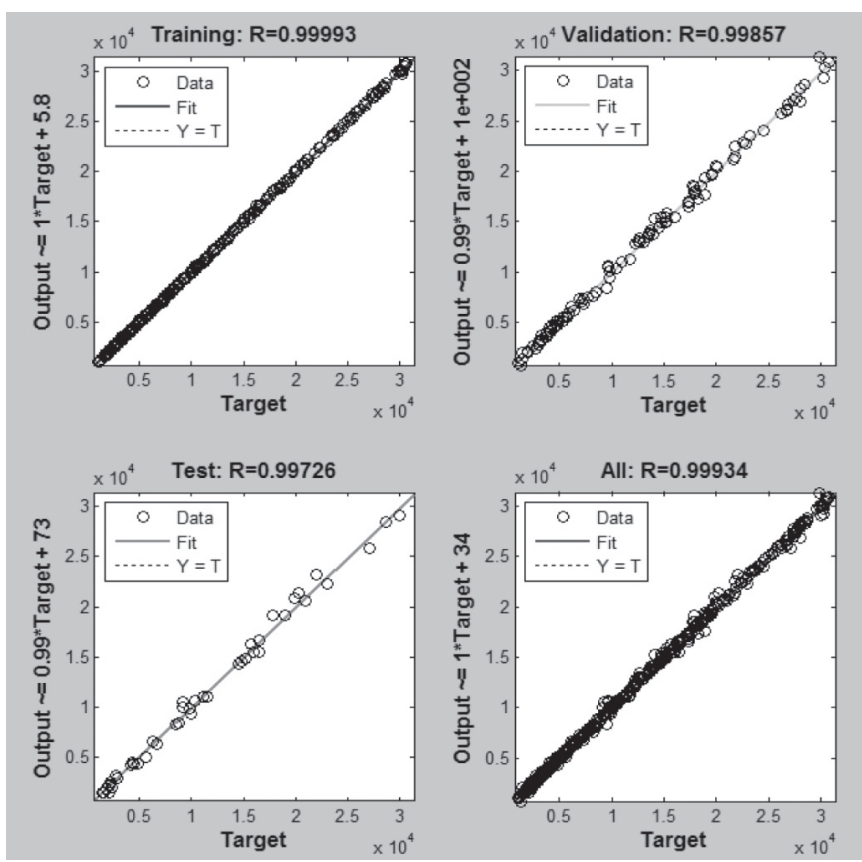

5. ábra Az elözetesen kapott eredmények statisztikai mutatói

Fig. 5. The statistical indexes of the preliminary results

A validált adatok alapján a korrelációs együttható magas értéke - megegyezően a nemzetközi eredményekkel - egyhez közelít, ami korábbi, hagyományos merevség-elörejelző modellekhez képest lényegesen pontosabb.

\section{Az eredmények finomítása: a Kohonen háló}

A háló tesztelése és az eredmények részletesebb tanulmányozása során azonban azt a következményt tapasztaltuk, hogy a háló merevség-elörejelző pontossága, ha eltérünk a tanításkor használt összetételi paraméterektől, romlik. A validációra kapott jó eredmény azzal magyarázható, hogy az ellenőrzés nem terjedt ki a szemeloszlási görbék kapcsolatának feltárására, a validált 
minták ugyanis ugyanarra a 6 szemeloszlási görbére estek, mint a tanítási minták, azaz a neurális háló csak interpolációs feladatot oldott meg. Ez egy várt következmény, lévén a fentiekben a hálók legfontosabb tulajdonságai között megemlítettük az extrapolációs hibát. Ez a hiba természetesen a jövőben az adatbázis fejlesztésével folyamatosan javítható, arra kell törekednünk, hogy a tanítási minta minél teljesebb körben lefedje mind a függő, mind a független változók teljes tartományát.

Jelen esetben azonban szemeloszlási görbe kisebb változtatása is a neurális háló pontatlan előrejelzéséhez vezethet. Az extrapolációs hibák kiküszöbölése osztályozási módszerrel valósítható meg. Az alapötletünk, hogy a különböző adalékok a szemeloszlási görbéjük karakterisztikáját tekintve besorolhatók az általunk definiált szemeloszlási görbék egyikéhez. A feladat vektor-klaszterezéssel végezhető el, mely egy speciális, második neurális hálózat alkalmazásának szükségességét veti fel. A célunk tehát az $n$-dimenziós ( $\mathrm{n}>2$ ) input minták egy kisebb dimenziós kimeneti réteg egy-egy elemére leképezni úgy, hogy a kívánt leképezés a bemeneti tér topológiai tulajdonságát megőrizze. Ugyanezt a logikai elvet követi az agy, „térbeli fogalmak” pl. hang, szag, vizuális és egyéb információk jelentéstartalmi szétválasztásánál, asszociációjánál.

A klaszterezést a Kohonen háló alkalmazásával értük el. Az önszervező térkép méretét $4 \times 4$-esnek definiáltuk, mozgásteret engedve korlátozott extrapolációra (6. ábra).

Kohonen háló

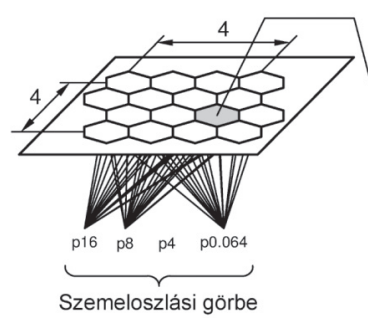

6. ábra A kombinált neuronhálózat vázlatos rajza

Fig. 6 . The rough sketch of the combined neuron network

A betanított Kohonen háló bármely szemeloszlási görbét egy-egy koordinátával párosított, így a bemenetek száma 2-vel csökkent. A görbék alapján az előállított koordinátákat felhasználva és a másik négy paraméterrel kombinálva az MLP korábbi extrapolációs hibája drasztikusan lecsökkent.

\section{5. Összefoglalás}

A neurális hálók aszfalttechnológiai alkalmazásának egyik lehetőségét három hazai aszfaltkeverék nagyszámú merevség vizsgálati adatsorát felhasználva mutattuk be. Igazoltuk, hogy az IT-CY vizsgálati eredményekre épített MLP háló a betanított tartományban nagy pontosságú merevség előrejelzésre képes, és hátránya ugyan a pontatlan extrapolációs képességében tetten érhető, ez az adatbázis folyamatos fejlesztésével folyamatosan javítható.

Átmeneti megoldásként a Kohonen-háló felhasználásával létrehoztunk egy olyan kombinált hálót, amely ezen extrapolációs hibákat jelentős mértékben képes csökkenteni, így a modell a járatos hazai keverékek esetén képes - a technológiailag elképzelhető - összes összetétel esetén merevség-előrejelzésre.

Jelen cikkben ugyan a keverékek merevségének az összetétel alapján történő prognosztizálhatóságára helyeztük a hangsúlyt, de természetesen a neurális hálók nagyszerüsége éppen univerzalitásukban rejlik, segítségükkel a keverékek tetszőleges jellemzője vizsgálható, előre jelezhető. Ennek fényében az aszfaltgyártás során az eddig nem vizsgált input-output adatok közötti kapcsolatok vizsgálatában minden érdeklődő számára nagy segítséget jelenthet.

Kutatásunk további célja lehet a genetikus programozás adta lehetőségek felhasználása aszfalt keverékek jellemzőinek vizsgálatánál. A genetikus programozás az evolúció biológiában ismert szelekciós elvet alkalmazza az emberi beavatkozás nélküli tervezéshez. Használatuk előnye abban mutatkozik, hogy a neurális háló fekete doboz jellegü megoldásaival ellentétben könnyen interpretálható modellek jönnek létre, így a kapott válasz egyenletek formájában is megadhatók.

\section{Felhasznált irodalom}

[1] Tóth Csaba: A teljesítményi szabályozás nyújtotta többletlehetőségek az útépitésben, X. Nemzetközi Építéstudományi Konferencia, Csíksomlyó, 2006. június. Kiadó: Erdélyi Magyar Müszaki Tudományos Társaság. Szerkesztő: Köllő Gábor. ISBN (10) 973-7840-13-5, pp 331-336.

[2] Dr. habil Fi I. - Tóth Cs.: A szemeloszlás-változás aszfaltkeverék merevségre gyakorolt hatásának prognosztizálhatósága. Közlekedésépítési Szemle, 60. évf. 2010/12. pp $24-31$.

[3] M. Saltan et al: Backcalculation of pavement layer moduli and Poisson's ratio using data mining. Expert Systems with Applications, Volume 38, Issue 3, March 2011, Pages 2600-2608

[4] E. Ozgan: Artificial neural network based modelling of the Marshall Stability of asphalt concrete. Expert Systems with Applications Volume 38, Issue 5, May 2011, Pages 6025-6030

[5] Dr. habil Fi, I. - Pethő, L. - Bocz, P. - Tóth, Cs.: Aszfaltkeverékek teljesítményének vizsgálata. KKK kutatási program, megrendelő: Közlekedésfejlesztési Koordinációs Központ. (2009)

[6] National Cooperative Highway Research Program: Guide for MechanisticEmpirical Design of New and Rehabilitated Pavement Structures. NCHRP 1-37-A: 2004

[7] Dr. Abonyi J. (szerk): Adatbányászat a hatékonyság eszköze. 2006

Ref.: http://dx.doi.org/10.14382/epitoanyag-jsbcm.2012.6

Koncsos Tamás - Tóth Csaba: Neurális hálók aszfalttechnológiai alkalmazása. Építőanyag, 64. évf. 1-2. szám (2012), 30-33. p.

\section{Ipari Gázok Katalógusa \\ - AZ ONLINE TUdÁSTÁR}

A gázok elôálításával, szállitásával, tárolásával és felhasználásával kapcsolatos legfontosabb információkat 216 oldalban összefoglaló Ipari Gázok Katalógusa már a www.messer.hu oldalon, elektronikus formában is elérhetô. A gázok részletes adatain és az azokkal kapcsolatos általános tudnivalókon kívül a katalógus beszámol a fốbb előállitási módszerek alapjairól, a szállítási-tárolási-ellátási formák és eszközök részleteitốl, a gázellátó és alkalmazástechnikai rendszerek adatairól, valamint a gázok helyes kezeléséhez szükséges biztonságtechnikai ismeretekrôl. Az e-katalógus elsốdleges célja, hogy segítséget nyújtson vevôinknek az ipari gázok célszerú és gazdaságos kiválasztásához, vásárlásához, kezeléséhez és felhasználásához.

http://messer.hu/Infotar/Ipari_Gazok_Katalogusa 